\title{
Sem Medo de Flutuar? O Regime Cambial Brasileiro Pós-1998
}

Francisco Eduardo Pires de Souza
Professor do Instituto de Economia da Universidade

Federal do Rio de Janeiro

\section{RESUMO}

O presente trabalho faz uma avaliação do arranjo cambial implantado no Brasil em 1999. Utilizando-se de indicadores do tipo Calvo-Reinhart faz-se uma comparação das características do regime brasileiro com o de outros países, com vistas a verificar se há evidências de "medo da flutuação". Tais indicadores mostram que o comportamento do governo deste país é bem mais intervencionista do que o de países que se caracterizam por uma flutuação genuína. Por outro lado, ao se fazer uma análise por períodos, percebe-se que, na ausência de choques externos fortes, o regime brasileiro se assemelhou a uma flutuação pura. Além disso, as evidências parecem sugerir que as autoridades monetárias manifestam medo maior de um desalinhamento grande da taxa real de câmbio do que da volatilidade cambial propriamente dita.

\section{PALAVRAS-CHAVE}

regime cambial brasileiro, flutuação cambial, medo da flutuação, arranjos cambiais

ABSTRACT

The aim of this paper is to assess the exchange rate arrangement adopted in Brazil since January 1999.

We use indicators of the Calvo-Reinhart type to evaluate if the monetary authorities in this country show fear of floating as compared to the cases of a number of other emerging economies as well as developed economies. Our results indicate that the Brazilian authorities intervene more intensively in the foreign exchange market than free floaters do. On the other hand, we can show, through an analysis period by period, that in the absence of strong external shocks, the Brazilian exchange rate arrangement

looks like a pure floating one. Moreover, the empirical evidence suggests that monetary authorities seems to be more concerned about a large misalignment of the real exchange rate, than about volatility.

KEY WORDS exchange rate arrangements, floating exchange rate, fear of floating, Brazilian exchange rate regime

JEL Classification

F3I, F33 


\section{INTRODUÇÃO}

Na década de 1990 o debate econômico sobre regimes cambiais foi dominado pela chamada visão bipolar. A tese, defendida originalmente por Eichengreen (1994), era de que num mundo com elevada mobilidade internacional de capitais não havia mais espaço para regimes cambiais intermediários. Só os extremos - união monetária ou flutuação - sobreviveriam no século XXI. ${ }^{1}$ A evidência empírica, proporcionada pelo FMI, parecia confirmar aquela proposição: se em 1980, 39\% dos países eram classificados pelo Fundo como tendo uma taxa de câmbio atrelada a alguma moeda de referência, em 1990 este porcentual reduziu-se para 19\% e em 1999 para 11\%. ${ }^{2}$ O regime de flutuação ganhava espaço, enquanto os regimes intermediários pareciam estar em franco processo de declínio.

Nos anos mais recentes, contudo, o debate vem ganhando novos rumos. Uma linha de investigação, inaugurada por Calvo e Reinhart (2000), parte da contestação às evidências empíricas sobre a adoção do regime de câmbio flutuante por um número crescente de países na década de 1990. Em vez de classificar os arranjos cambiais de acordo com aquilo que é declarado pelos países ao FMI, procurou-se criar indicadores objetivos que identificassem a real natureza dos regimes cambiais adotados. Os resultados obtidos pelos primeiros trabalhos dentro desta linha de pesquisa ${ }^{3}$ mostraram que a grande maioria de países que declaravam ter adotado o regime de câmbio flutuante recorria, na prática, a um conjunto de medidas voltadas para a estabilização de suas taxas de câmbio. Este tipo de comportamento deu origem à expressão fear of floating.

A literatura do fear of floating ${ }^{4}$ baseia-se num conjunto de indicadores para os países emergentes que supostamente adotam a flutuação livre, cujos valores parecem confirmar a suspeita de administração da taxa de câmbio. Tais indicadores mostram uma volatilidade da taxa de câmbio bem menor e uma volatilidade das reservas e das taxas de juros bem maior do que a observada nos casos de flutuação genuína, presente em países como os EUA e o Japão.

Várias razões foram apontadas para justificar o medo da flutuação. Calvo e Reinhart (2000) destacaram o descasamento de moedas entre passivos e ativos (currency misma-

1 FISCHER (2001) faz uma revisão desta tese e reconhece que houve um exagero na proposição original.

2 Informações obtidas nos relatórios anuais do FMI sobre arranjos e restrições cambiais. (FMI, 1999).

3 Além do já citado trabalho de CALVO \& REINHART (2000), outros trabalhos representativos desta literatura são os de GOLDFJAN \& OLIVARES (2001), SILVEIRA (2003), EICHENGREEN, HAUSMANN \& PANIZZA (2002), HAUSMANN et al. (2000), MUSSA et al. (2000), REINHART (2000) e STURZENEGGER \& LEVYYYYATI (2002). Estes últimos refizeram a classificação dos regimes cambiais de todos os países, baseados em indicadores objetivos.

4 Vide, por exemplo, CALVO \& REINHART (2000), GOLDFJAN \& OLIVARES (2001), EICHENGREEN, HAUSMANN \& PANIZZA (2002), HAUSMANN, PANIZZA \& STEIN (2000), MUSSA et al. (2000), REINHART (2000), STURZENEGGER \& LEVYYYYATI (2002) e MCKINNON \& SCHNABL (2003). 
tching) e a falta de credibilidade da política econômica, que torna o câmbio uma âncora para os preços mais eficaz do que a política monetária. O primeiro fator, batizado como "o problema do pecado original", está no centro das análises de Hausmann et al. (2000). Goldfajn e Olivares (2001), certamente influenciados pelo caso brasileiro, enfatizam o fenômeno do pass-through do câmbio para a inflação, ou seja, ofear of inflation, que seria maior no caso das economias emergentes.

Em suma, considerando que a maioria dos recém-convertidos à flutuação pratica, na verdade, formas disfarçadas de fixação da taxa de câmbio, a literatura recente conclui que a idéia usual de que os chamados regimes cambiais intermediários estão desaparecendo é um mito. Assim sendo, as economias emergentes continuariam vulneráveis a ataques especulativos e crises cambiais. Três alternativas restariam, então, para enfrentar o problema: a dolarização/união monetária; a adoção de taxas de câmbio fixas, associadas a controles da conta capital; ou uma terapia destinada a suprimir as causas do medo de flutuar na linha sugerida por Eichengreen, Hausmann e Panizza (2002), de redenção do "pecado original".

O novo governo brasileiro, empossado em janeiro de 2003, reiterou a opção de seu antecessor no que se refere aos regimes cambial e monetário. A opção de 1999 - flutuação do câmbio e metas inflacionárias -, que se encontrava ameaçada pelos distúrbios cambiais e aceleração inflacionária do final do governo Fernando Henrique Cardoso, foi resgatada e fortalecida. Mas até que ponto o caso da economia brasileira se enquadra no fenômeno geral do medo da flutuação? Qual o grau de divergência entre discurso e a realidade do regime cambial? Tendo por referência o debate acima indicado, o presente texto pretende fazer uma avaliação do arranjo cambial brasileiro implantado no início de 1999, em dois planos. O primeiro consiste em identificar o quanto ele se aproxima ou se afasta de um regime de flutuação genuína. $\mathrm{O}$ outro se refere à adequação deste regime para o Brasil na atualidade, relacionando-se os prós e contras.

Na seção 1, a seguir, examinam-se alguns indicadores de "medo da flutuação" para um painel de países, incluindo o Brasil, para o período 1999-2002, nos moldes dos estudos típicos da literatura sobre o tema. A partir da seção 2 o trabalho concentra-se apenas no caso brasileiro. Ao focar a análise num caso individual, pode-se operar com uma quantidade maior de variáveis e com informações qualitativas que são dificilmente manejáveis no âmbito dos estudos que trabalham com um grande painel de países. Além disso, pode-se examinar a evolução do regime cambial ao longo do tempo, identificando as mudanças ocorridas. Isto posto, a seção 3 avalia vantagens e os inconvenientes da flutuação no caso brasileiro, com o objetivo de tentar entender a opção brasileira em relação ao regime cambial efetivamente adotado, à luz dos problemas levantados pela literatura e de outros desafios relacionados à vulnerabilidade externa do país. A última seção faz uma breve síntese conclusiva. 


\section{INDICADORES BÁSICOS DE "FEAR OF FLOATING": O BRASIL EM COMPA- RAÇÃO A CASOS DE FLUTUAÇÃO ESPÚRIA E GENUÍNA}

O ponto de partida da literatura do fear of floating foi a construção de indicadores quantitativos - os "testes Calvo-Reinhart de flutuação destemida", conforme expressão de Williamson (2000) - destinados a captar as verdadeiras características dos arranjos cambiais de diferentes grupos de países. Nesta seção usaremos indicadores deste gênero para comparar o regime cambial do Brasil no período 1999-2002 com os de outros países no mesmo período e com o próprio regime brasileiro na primeira fase do Plano Real (1994-1998).

A idéia subjacente a estes indicadores é que sob um regime de flutuação genuína a volatilidade da taxa de câmbio é relativamente alta, ao mesmo tempo que as volatilidades das reservas internacionais e das taxas de juros são relativamente baixas - já que sob livre flutuação não são necessárias intervenções freqüentes no mercado de câmbio com o objetivo de estabilizar as cotaçôes da moeda estrangeira, enquanto que a taxa de juros é fixada tendo somente em conta os objetivos internos de política econômica. Neste sentido, países que apresentam altas volatilidades relativas nas reservas internacionais e na taxa de juros não passam no teste Calvo-Reinhart, e seus regimes cambiais devem ser enquadrados em alguma categoria intermediária entre o permanentemente fixo e o flutuante. Tal procedimento permite classificar os regimes cambiais adotados por um critério de facto em oposição à classificação de jure - baseada na autodescrição -, com implicaçôes importantes para a avaliação do desempenho dos regimes cambiais, conforme discutido, por exemplo, por Goldstein (2002) e Sturzenegger e Levy-Yeyati (2002).

A Tabela $\mathrm{l}$ a seguir é uma versão ligeiramente modificada e atualizada daquela construída por Calvo e Reinhart (2000) para períodos anteriores a 2000. Nela apresentamos os resultados de um exercício para o período 1999-2002, para Estados Unidos, Japão, Brasil e algumas outras economias emergentes que adotaram o regime de câmbio flutuante. As três últimas colunas mostram a distribuição de freqüência das variações mensais da taxa de câmbio. ${ }^{5}$ Quanto maior a freqüência das observaçôes além dos limites considerados ( $1 \%$ e $2,5 \%),{ }^{6}$ maior a variação da taxa de câmbio e, portanto, mais

5 CALVO \& REINHART (2000) trabalharam com taxas de final de período. Contudo, o uso de taxas médias por período nos pareceu mais adequado, tendo em vista que taxas diárias estão mais sujeitas a variações episódicas, sendo menos representativas do ocorrido no período. Por outro lado, para poder comparar nossos resultados para o período mais recente com os dos autores, acrescentamos anexos os valores para o exercício com taxas de fim de período. As diferenças são pequenas e não afetam as conclusões.

6 Para se ter parâmetros para avaliar os intervalos contidos na tabela, o limite mais baixo, de 1\%, corresponde à banda de flutuação de regimes de câmbio fixo, como Bretton Woods. Portanto, uma economia cujas variaçôes da taxa de câmbio fiquem, na maior parte das vezes, abaixo deste limite, ou tem regime de câmbio fixo ou mesmo que declare outro regime, tem medo de flutuar. Por sua vez, a banda de $2,5 \%$ é próxima, por exemplo, da regra para as moedas européias antes da crise cambial de $1992(+/-2,25 \%)$. 
próximo de um regime de câmbio flutuante está o país. Dado que os EUA têm mantido - apesar de intervenções esporádicas - um regime de câmbio flutuante tão autêntico quanto o permitido pelas circunstâncias do mundo real, ${ }^{7}$ adotaremos, seguindo a literatura, os números desse país como critério para aferir os demais regimes cambiais. Para medir a volatilidade do valor da moeda americana, usaremos sua taxa de câmbio em relação ao euro, enquanto que para todas as demais, a taxa de câmbio será o valor da respectiva moeda em relação ao dólar.

\section{TABELA 1 - VOLATILIDADE DA TAXA DE CÂMBIO (MÉDIA DO PERÍODO)}

\begin{tabular}{|c|c|c|c|c|}
\hline \multirow[t]{2}{*}{ País } & \multirow[t]{2}{*}{ Período } & \multicolumn{3}{|c|}{$\begin{array}{l}\text { Freqüência na qual a variação mensal } \\
\text { da taxa de câmbio: }\end{array}$} \\
\hline & & $\begin{array}{l}\text { Ficou dentro da } \\
\text { banda de }+/-1 \%\end{array}$ & $\begin{array}{c}\text { Ficou dentro da } \\
\text { banda de }+/- \\
2,5 \%\end{array}$ & $\begin{array}{l}\text { Excedeu a banda } \\
\text { de }+/-2,5 \%\end{array}$ \\
\hline Turquia & jan/99 a set/02 & $18 \%$ & $24 \%$ & $76 \%$ \\
\hline Argentina & jan/02 a dez/02 & $33 \%$ & $42 \%$ & $58 \%$ \\
\hline Brasil & jan/99 a dez/02 & $17 \%$ & $46 \%$ & $54 \%$ \\
\hline Nova Zelândia & jan/99 a dez/02 & $25 \%$ & $58 \%$ & $42 \%$ \\
\hline Chile & jan/99 a dez/02 & $25 \%$ & $63 \%$ & $38 \%$ \\
\hline África do Sul & jan/99 a dez/02 & $33 \%$ & $67 \%$ & $33 \%$ \\
\hline Austrália & jan/99 a dez/02 & $29 \%$ & $67 \%$ & $33 \%$ \\
\hline Paraguai & jan/99 a dez/02 & $56 \%$ & $67 \%$ & $33 \%$ \\
\hline EUA (dólar/euro) & jan/99 a dez/02 & $23 \%$ & $68 \%$ & $32 \%$ \\
\hline Japão & jan/99 a dez/02 & $27 \%$ & $69 \%$ & $31 \%$ \\
\hline Polônia & jan/99 a set/02 & $31 \%$ & $73 \%$ & $27 \%$ \\
\hline Uruguai & jan/99 a dez/02 & $46 \%$ & $75 \%$ & $25 \%$ \\
\hline Coréia do Sul & jan/99 a dez/02 & $44 \%$ & $79 \%$ & $21 \%$ \\
\hline México & jan/99 a dez/02 & $48 \%$ & $81 \%$ & $19 \%$ \\
\hline Venezuela & jan/99 a dez/02 & $46 \%$ & $81 \%$ & $19 \%$ \\
\hline Rússia & jan/99 a out/02 & $63 \%$ & $83 \%$ & $17 \%$ \\
\hline Tailândia & jan/99 a dez/02 & $40 \%$ & $83 \%$ & $17 \%$ \\
\hline Israel & jan/99 a out/02 & $61 \%$ & $89 \%$ & $11 \%$ \\
\hline Cingapura & jan/99 a dez/02 & $63 \%$ & $96 \%$ & $4 \%$ \\
\hline Canadá & jan/99 a dez/02 & $50 \%$ & $100 \%$ & $0 \%$ \\
\hline Média dos emergentes exceto Brasil & jan/99 a dez/02 & $43 \%$ & $72 \%$ & $28 \%$ \\
\hline EUA (dólar/marco) & $\mathrm{fev} / 73 \mathrm{a} a b r / 99$ & $27 \%$ & $59 \%$ & $41 \%$ \\
\hline
\end{tabular}

Fontes: CALVO \& REINHART (2000), Banco de Dados do Grupo de Conjuntura (UFRJ), Fed, IFS, Banco Central do Chile, Banco Central do Paraguai, Ministério da Economia Argentina e Banco Central do Uruguai.

7 Uma interessante e extensiva análise do regime cambial americano, documentando as intervençôes no mercado de câmbio de 1973 ao início dos anos 1990, seus objetivos e eficiência, encontra-se em FRANKEL \& DOMINGUEZ (1993). 
Como pode ser observado na Tabela 1 , tomando-se o caso americano como padrão de referência, e considerando-se como indicador da flutuação apenas a volatilidade da taxa de câmbio, verifica-se que nos últimos quatro anos o regime cambial brasileiro se comportou como genuinamente flutuante. De fato, a taxa de câmbio brasileira exibiu maior flutuação do que a taxa de câmbio do dólar em relação ao marco (ou ao euro), tanto quando esta última é medida no período 1973-1999 - dados de Calvo e Reinhart (2000) - quanto no período 1999-2002. De fato, nestes últimos quatro anos a taxa de câmbio nominal brasileira oscilou menos do que $2,5 \%$ ao mês em $46 \%$ dos casos. Visto por outra ótica, isto significa que em $54 \%$ dos meses a taxa de câmbio R\$/US\$ variou mais do que $2,5 \%$ em relação ao mês anterior. Já o benchmark americano apresentou uma freqüência de $68 \%$ (ou 59\% no período 1973-99) para variaçóes cambiais abaixo de 2,5\%; ou seja, em 32\% dos casos a taxa de câmbio do dólar em relação ao euro variou mais do que $2,5 \%$ de um mês para o outro (contra $54 \%$ no caso brasileiro).

É interessante notar que os resultados da tabela acima mostram que no período 1999 2002 as economias emergentes como um todo revelaram um medo da flutuação (medido apenas pelo indicador acima) muito menor do que o identificado por Calvo e Reinhart (2000) para um período anterior.

Tomado isoladamente, o indicador acima não é suficiente para fechar um diagnóstico de que um país tem ou não a síndrome do medo da flutuação. É necessário investigar todos os sintomas em conjunto. Uma alta volatilidade da taxa de câmbio não necessariamente significa a ausência de fear of floating. Ela pode ser resultado de choques intensos. E o Brasil sofreu muitos choques financeiros no período, o que nos remete à possibilidade de que a alta volatilidade na taxa de câmbio brasileira não seja sintoma de flutuação destemida. O passo seguinte na investigação consiste em indagar se a alta volatilidade relativa exibida no período pela taxa de câmbio brasileira (bem como pelas de outras economias emergentes) náo foi resultado da intensidade dos choques a que esteve submetido o País. Ou seja, cabe testar se o ocorrido deveu-se, a despeito de esforços para estabilizar a taxa de câmbio, ao fato de não ter sido possível alcançar o resultado desejado.

Para testar a hipótese de que a alta volatilidade refletiu a ausência de medo da flutuação, cabe verificar as ações da autoridade monetária cujo objetivo seria estabilizar a taxa de câmbio. Algumas delas são passíveis de quantificação, enquanto outras são mais dificilmente transformáveis em indicadores. No que resta desta seção, nos limitaremos a examinar a volatilidade das reservas e da taxa de juros, por serem estes indicadores mais facilmente comparáveis entre países, deixando para a seção seguinte, que trata do caso brasileiro, o exame de outras formas de intervenção. 
Antes de prosseguir, deve-se observar que tomar simplesmente a variação das reservas pode não ser um bom indicador do comportamento das autoridades monetárias, dado que as reservas podem variar por diversas razões não relacionadas com intervenções no mercado de câmbio (valorizações, desvalorizações, empréstimos tomados do FMI, pagamentos de juros e amortizações de empréstimos contraídos pelas autoridades monetárias etc.). Ao mesmo tempo, intervençôes podem ocorrer fazendo-se uso de linhas de crédito sem perda de reservas (como no caso de países europeus que recebiam linhas de crédito dos demais para intervir nos seus mercados de câmbio, antes do advento da moeda única, por meio do mecanismo de taxas cambiais fixas adotado ${ }^{8}$ ). Por esta razão, seria interessante trabalhar diretamente com informaçốes de intervenção nos mercados de câmbio. No caso do Brasil, o Banco Central disponibiliza estes dados, sendo eles usados na comparação com os dados de variação de reservas.

Na Tabela 2, nota-se que a volatilidade das reservas brasileiras ( $54 \%$ de variaçóes mensais acima de 2,5\%) é bem maior que a observada em países como os EUA (23\%) e o Japão $(21 \%)$, por exemplo. E embora a volatilidade baixe um pouco quando consideramos apenas a variação das reservas resultante de intervenções (de 54\% para $44 \%$ ), ainda assim chegamos a uma volatilidade bem superior à dos países de referência.

Uma primeira leitura dos resultados combinados das Tabelas 1 e 2 poderia nos levar à conclusão que, de fato, no caso do Brasil, o Banco Central tentou evitar a flutuação, porém sem lograr êxito. Ou seja, apesar de intervir muito no mercado (como mostrado na Tabela 2) não conteve a alta volatilidade da taxa de câmbio (Tabela 1).

Uma leitura alternativa, contudo, poderia questionar a comparação de reações de autoridades monetárias submetidas a circunstâncias muito distintas. Como os países de referência não foram sujeitos a choques tão grandes quanto o Brasil (e outros emergentes), seu compromisso com a flutuação cambial pura não foi testada em condições altamente adversas. De fato, se distinguirmos, no caso brasileiro, as intervenções realizadas nos casos em que a variação da taxa de câmbio mensal foi menor que $5 \%$ e aquelas que ocorreram em resposta a variações superiores a esta marca, verificaremos que no primeiro caso as intervenções se limitaram a $20 \%$ das observações, enquanto que no segundo elas corresponderam a $54 \%$ das observações. ${ }^{9}$ É verdade que um teste semelhante para os EUA, no mesmo período, mostra uma virtual ausência de intervençôes no mercado de câmbio. Por outro lado, a taxa de câmbio US\$/euro variou mais de $5 \%$ em apenas um mês da amostra, contra 13 vezes no caso da taxa RS/USS.

8 Conhecido pela sigla ERM, que significava Exchange Rate Mechanism.

9 Este teste foi feito usando-se os dados de intervenção (e não de variação de reservas) e considerando-se como intervenção os casos em que se gastou mais de 1\% das reservas e na "direção certa" (isto é, venda de reservas em meses de depreciação e compra de reservas em meses de apreciação). 
TABELA 2 - VOLATILIDADE DAS RESERVAS INTERNACIONAIS

\begin{tabular}{|c|c|c|c|c|}
\hline \multirow[t]{2}{*}{ País } & \multirow[t]{2}{*}{ Período } & \multicolumn{3}{|c|}{$\begin{array}{l}\text { Freqüência na qual a variação mensal } \\
\text { das reservas internacionais: }\end{array}$} \\
\hline & & $\begin{array}{l}\text { Ficou dentro da } \\
\text { banda de }+/-1 \% \mathrm{~b}\end{array}$ & $\begin{array}{l}\text { Ficou dentro da } \\
\text { banda de }+/-2,5 \%\end{array}$ & $\begin{array}{l}\text { Excedeu a banda } \\
\text { de }+/-2,5 \%\end{array}$ \\
\hline Cingapura & jan/99 a set/02 & $62 \%$ & $93 \%$ & $7 \%$ \\
\hline Chile & jan/99 a dez/02 & $44 \%$ & $85 \%$ & $15 \%$ \\
\hline Israel & jan/99 a out/02 & $54 \%$ & $85 \%$ & $15 \%$ \\
\hline Tailândia & jan/99 a dez/02 & $44 \%$ & $83 \%$ & $17 \%$ \\
\hline Japão & jan/99 a dez/02 & $58 \%$ & $79 \%$ & $21 \%$ \\
\hline África do Sul & jan/99 a out/02 & $39 \%$ & $78 \%$ & $22 \%$ \\
\hline Canadá & jan/99 a dez/02 & $31 \%$ & $77 \%$ & $23 \%$ \\
\hline EUA & jan/99 a dez/02 & $40 \%$ & $77 \%$ & $23 \%$ \\
\hline Polônia & jan/99 a set/02 & $49 \%$ & $73 \%$ & $27 \%$ \\
\hline México & jan/99 a dez/02 & $40 \%$ & $73 \%$ & $27 \%$ \\
\hline Coréia do Sul & jan/99 a dez/02 & $33 \%$ & $63 \%$ & $38 \%$ \\
\hline Brasil (1) & jan/99 a dez/02 & $52 \%$ & $56 \%$ & $44 \%$ \\
\hline Brasil & jan/99 a dez/02 & $23 \%$ & $46 \%$ & $54 \%$ \\
\hline Turquia & jan/99 a out/02 & $22 \%$ & $43 \%$ & $57 \%$ \\
\hline Austrália & jan/99 a dez/02 & $27 \%$ & $42 \%$ & $58 \%$ \\
\hline Uruguai & jan/99 a dez/02 & $13 \%$ & $38 \%$ & $63 \%$ \\
\hline Rússia & jan/99 a set/02 & $16 \%$ & $31 \%$ & $69 \%$ \\
\hline Venezuela & jan/99 a dez/02 & $10 \%$ & $27 \%$ & $73 \%$ \\
\hline Nova Zelândia & jan/99 a set/02 & $13 \%$ & $27 \%$ & $73 \%$ \\
\hline Argentina & jan/02 a dez/02 & $0 \%$ & $25 \%$ & $75 \%$ \\
\hline Paraguai & jan/99 a dez/02 & $15 \%$ & $21 \%$ & $79 \%$ \\
\hline $\begin{array}{l}\text { Média dos emergentes } \\
\text { exceto Brasil }\end{array}$ & jan/02 a dez/02 & $31 \%$ & $58 \%$ & $42 \%$ \\
\hline EUA & $\mathrm{fev} / 73$ a abr/99 & $29 \%$ & $62 \%$ & $38 \%$ \\
\hline
\end{tabular}

Fontes: CALVO \& REINHART (2000), IFS, Banco Central Europeu e Banco Central do Brasil (Séries Temporais e Notas para Imprensa).

(1) Considerando-se como variação nas reservas apenas as intervençóes no mercado de câmbio (dados disponíveis nas Notas para Imprensa do Banco Central do Brasil - Setor Externo).

Adicionalmente, há um problema de comparabilidade entre as três principais moedas (dólar americano, euro e iene) e as demais. Enquanto as intervenções feitas pela maior parte das economias são unilaterais, freqüentemente as intervenções para conter a depreciação ou apreciação do dólar são feitas via operações coordenadas entre mais de 
um banco central, de modo que a intervenção realizada por um deles para estabilizar sua moeda parece ser menor do que efetivamente foi.

Por fim, resta analisar o comportamento das taxas de juros. Como mostra a Tabela 3, a taxa brasileira é muito mais volátil que a americana. Enquanto somente em $8 \%$ dos casos a variação mensal da taxa de juros norte-americana excedeu a banda de 0,5 ponto porcentual, no caso brasileiro isto ocorreu em $85 \%$ dos casos.

TABELA 3 - VOLATILIDADE DA TAXA DEJUROS

\begin{tabular}{lcccc}
\hline País & Período & \multicolumn{3}{c}{ Freqüência na qual a variação mensal da taxa de juros: } \\
\cline { 2 - 5 } & & $\begin{array}{c}\text { Ficou entre }+/- \\
0,25 \text { pontos } \\
\text { porcentuais }\end{array}$ & $\begin{array}{c}\text { Ficou entre }+/- \\
0,50 \text { pontos } \\
\text { porcentuais }\end{array}$ & $\begin{array}{c}\text { Excedeu }+/- \\
0,5 \text { pontos } \\
\text { porcentuais }\end{array}$ \\
\hline Austrália & jan/99 a set/02 & $87 \%$ & $100 \%$ & $0 \%$ \\
Japão & jan/99 a dez/02 & $100 \%$ & $100 \%$ & $0 \%$ \\
Canadá & jan/99 a dez/02 & $88 \%$ & $98 \%$ & $2 \%$ \\
Nova Zelândia & jan/99 a out/02 & $74 \%$ & $98 \%$ & $2 \%$ \\
Coréia do Sul & jan/99 a dez/02 & $90 \%$ & $94 \%$ & $6 \%$ \\
EUA & jan/99 a dez/02 & $75 \%$ & $92 \%$ & $8 \%$ \\
Cingapura & jan/99 a out/02 & $63 \%$ & $87 \%$ & $13 \%$ \\
Tailândia & jan/99 a out/02 & $63 \%$ & $87 \%$ & $13 \%$ \\
Chile & jan/99 a dez/02 & $67 \%$ & $83 \%$ & $17 \%$ \\
África do Sul & jan/99 a out/02 & $52 \%$ & $72 \%$ & $28 \%$ \\
Israel & jan/99 a out/02 & $46 \%$ & $70 \%$ & $30 \%$ \\
Polônia & jan/99 a jul/02 & $28 \%$ & $47 \%$ & $53 \%$ \\
Turquia & jan/99 a jul/02 & $28 \%$ & $30 \%$ & $70 \%$ \\
México & jan/99 a out/02 & $13 \%$ & $22 \%$ & $78 \%$ \\
Brasil & jan/99 a dez/02 & $10 \%$ & $15 \%$ & $85 \%$ \\
Uruguai & jan/99 a ago/02 & $7 \%$ & $14 \%$ & $86 \%$ \\
Rússia & jan/99 a set/02 & $2 \%$ & $11 \%$ & $89 \%$ \\
Paraguai & jan/99 a set/02 & $4 \%$ & $11 \%$ & $89 \%$ \\
Venezuela & jan/99 a set/02 & $4 \%$ & $9 \%$ & $91 \%$ \\
Argentina & jan/02 a dez/02 & $0 \%$ & $0 \%$ & $100 \%$ \\
\hline Média dos emergentes & jan/02 a dez/02 & $33 \%$ & $45 \%$ & $55 \%$ \\
exceto Brasil & & & & \\
EUA & fev/73 a abr/99 & $60 \%$ & $81 \%$ & $19 \%$ \\
\hline E & & & 9 & \\
\hline
\end{tabular}

Fontes: CALVO \& REINHART (2000), OECD, IFS, Fed, Ministério da Economia Argentina, Banco Central do Canadá, Banco Central do Chile e Banco Central do Brasil (Séries Temporais). OBS: A taxa de juros de Israel é a dos títulos do Tesouro, as demais são taxas de mercado. 
Novamente cabe fazer ressalvas ao interpretar os resultados. Desta vez, por causa das disparidades de níveis absolutos de taxas de juros. Cada ponto porcentual de variação na taxa de juros representa uma variação proporcional menor e, certamente, um uso menos intensivo da política monetária, no caso de países com níveis de juros médios mais elevados. E países com inflação média mais alta tendem a operar, coeteris paribus, com taxas de juros nominais mais elevadas.

Uma segunda ressalva refere-se ao fato de que não se pode atribuir toda mudança na taxa de juros a tentativas de estabilizar a taxa de câmbio. No caso brasileiro recente, dado o regime de metas de inflação adotado, a própria volatilidade das pressóes inflacionárias é uma causa importante da volatilidade da taxa de juros.

Em suma, a caracterização do regime cambial brasileiro não é simples. Dos três indicadores apresentados nas tabelas acima, o da volatilidade da taxa de câmbio é consistente com um regime de flutuação genuína, enquanto os dois outros sugerem medo de flutuar. Contudo, tendo em conta as ressalvas acima, no que concerne à interpretação dos indicadores de volatilidade das reservas e das taxas de juros, o conjunto de evidências apresentado até aqui parece insuficiente para fazer um diagnóstico preciso sobre se a epidemia do fear of floating atingiu ou não o Brasil. Para tentar avançar neste terreno, a seção a seguir trata da experiência brasileira com mais detalhes, recorrendo-se a indicadores adicionais e a uma análise por período.

\section{UMA ECONOMIA EMERGENTE EM BUSCA DA FLUTUAÇÃO PURA}

Muitos dos países que sofreram ataques especulativos e crises cambiais adotaram a flutuação como um expediente temporário para enfrentar uma situação em que não tinham mais como intervir no mercado de câmbio para sustentar uma paridade fixa. $\grave{A}$ medida que a situação se normalizava, os bancos centrais voltavam a tentar estabilizar a taxa de câmbio - em alguns casos, como na Malásia, de forma explícita. ${ }^{10}$

O Brasil, ao contrário, pode ser incluído num outro grupo de economias emergentes, que após a crise cambial aderiu ao regime de câmbio flutuante como uma opção permanente. Esta opção foi não apenas reiterada seguidamente no discurso das autoridades econômicas, como também no arranjo institucional criado a partir de 1999, que incorporou um regime de metas inflacionárias, de acordo com o qual a política monetária seria conduzida exclusivamente em função da meta para a inflação. Apesar disso, e como os dados da seção anterior mostraram, houve um volume suficientemente eleva-

$10 \mathrm{E}$, de forma implícita, muitas outras. A Coréia e a Tailândia são freqüentemente citadas como economias que, apesar de se declararem num regime de flutuação, mantêm suas taxas de câmbio tão estáveis que mais parecem um regime de câmbio fixo do que flutuante. 
do de intervençóes no mercado de câmbio para pôr em dúvida o compromisso efetivo com a flutuação.

No que se segue, procuraremos descrever sucintamente o comportamento das autoridades monetárias em relação ao mercado de câmbio, distinguindo quatro períodos, caracterizados por conjunturas e choques peculiares, que em alguns casos puseram severamente à prova o compromisso com a flutuação. Para que se tenha uma visão geral do comportamento das autoridades econômicas desde o início da flutuação, bem como das diferenças que marcaram os 4 subperíodos que serão analisados a seguir, o Gráfico 1 mostra as intervenções do Banco Central no mercado de câmbio por meio da venda (-) ou compra (+) de moeda estrangeira, de 1998 (último ano antes da flutuação) $)^{11}$ a 2002.

\section{GRÁFICO 1 - INTERVENÇÕES DO BANCO CENTRAL NO MERCADO DE CAMBIO (JAN/98 A DEZ/02)}

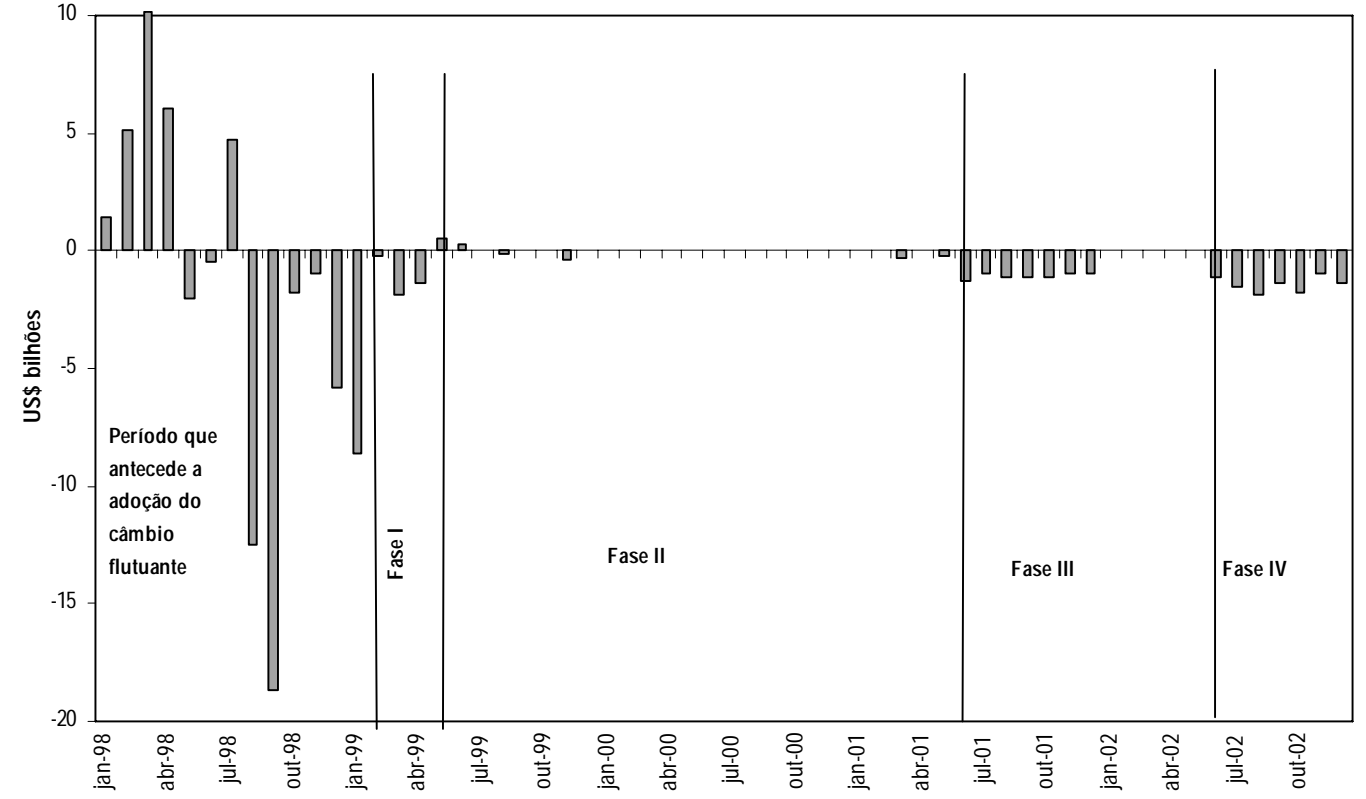

Fonte: Banco Central do Brasil, Notas para a Imprensa - Setor Externo, vários números. Elaboração do autor.

11 Foram excluídas do Gráfico 3 operações de intervenção por razões muito específicas e que pouco teriam a ver com a tentativa de influir na taxa de câmbio. Foram duas as operações de venda e compra casadas de final de ano - uma delas para prevenir problemas associados ao bug do milênio, e a compra das divisas oriundas do privatização do BANESPA. 
Fase 1: A implantação do novo regime

O Brasil adotou o regime de flutuação a partir do dia 18 de janeiro de $1999 .{ }^{12}$ No primeiro mês e meio que se seguiu à mudança, a taxa de câmbio disparou impulsionada pelo profundo desequilíbrio no mercado de câmbio. A causa do desequilíbrio foi a continuação de uma elevada saída líquida de capitais derivada da incerteza que cercava o futuro das instituições e da política econômica. A partir da confirmação, pelo Senado, do nome do novo presidente do Banco Central a taxa de câmbio começou a ceder, tendência que foi reforçada pela nova definição da política monetária (acompanhada de forte elevação dos juros) e pelo sucesso da revisão do acordo com o FMI ainda no mês de março. O Gráfico 2 a seguir mostra esta evolução.

\section{GRÁFICO 2 - EVOLUÇÃO DA TAXA DE CÂMBIO NOMINAL R\$/US\$ APÓS A MUDANÇA DO REGIME CAMBIAL}

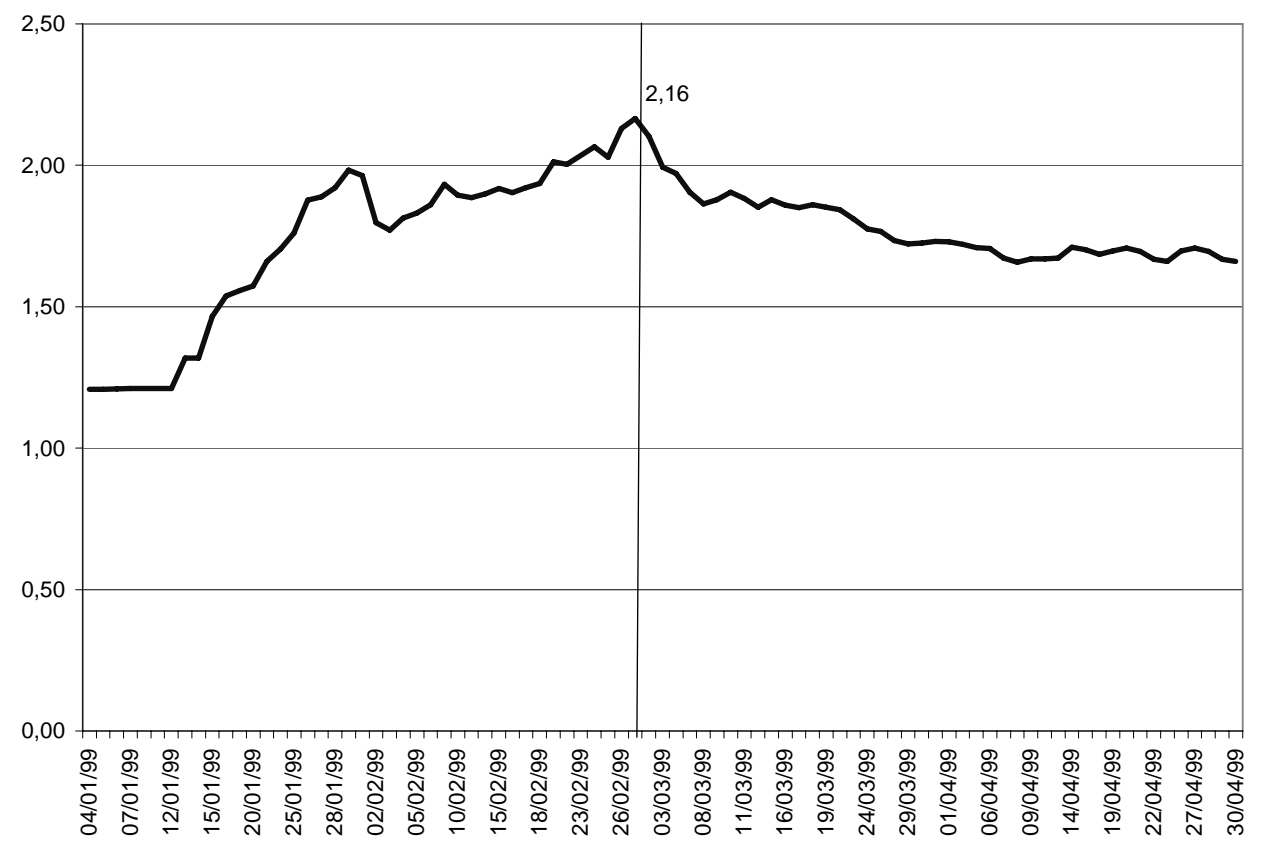

Fonte: Banco Central do Brasil, www.bcb.gov.br. Elaboração do autor.

12 Comunicado $\mathrm{n}^{\circ} 6565$ do Banco Central do Brasil, que anunciava que a partir daquele dia a taxa de câmbio seria determinada pelo mercado, cabendo ao Banco Central intervir apenas eventualmente para conter movimentos desordenados do câmbio. 
Embora tenha deixado o real flutuar, o Banco Central procurou conter o nível da depreciação da moeda, por meio de volumosas vendas de moeda estrangeira no mercado de câmbio. ${ }^{13}$ De janeiro a abril, o Banco Central vendeu US\$ 12 bilhões ( $1 / 3$ do estoque de reservas no início do período) na tentativa de moderar a alta das cotações do dólar. Mas, destes, US\$ 7,6 bilhões foram vendidos na primeira quinzena de janeiro, antes da mudança do regime cambial, de forma que após o início da flutuação as vendas foram de cerca de US\$ 4,4 bilhões. Apesar dessas intervenções, a taxa de câmbio chegou a subir 57\% ao longo do primeiro trimestre (média de março em relação à média de dezembro de 1998), cedendo depois para uma alta de $41 \%$ no mês de abril (também contra a média de dezembro de 1998). Ou seja, a alta volatilidade das reservas ocorreu numa fase de extrema volatilidade da taxa de câmbio relacionada às peculiares circunstâncias que envolveram a transição para o novo regime - profunda incerteza quanto ao futuro da política econômica e overshooting cambial. Por esta razão, parece recomendável considerar este período como excepcional e destacá-lo dos demais para fins de caracterização do regime cambial brasileiro pós 1998.

Ao final deste breve período, contudo, começava a se cristalizar uma definição das regras do regime de flutuação. É verdade que estas encerravam uma certa ambigüidade: o Banco Central assumia um compromisso com a livre flutuação e ao mesmo tempo com intervenções cambiais cuja lógica não era inteiramente consistente com a opção feita. Assim, no âmbito da revisão do acordo com o FMI (março de 1999), foram estabelecidos limites ${ }^{14}$ e critérios para a intervenção no mercado de câmbio. A intervenção seria admissível em duas circunstâncias: para se contrapor a condições de desordem no mercado cambial e para atender às necessidades projetadas de financiamento do balanço de pagamentos. ${ }^{15} \mathrm{O}$ primeiro motivo, embora sujeito a uma apreciação subjetiva,

13 Conforme o documento Análise do Mercado de Cámbio, Jan-Mar de 1999, do Banco Central, "a partir daquela data (22/02/99), a mesa de cámbio passon a operar com maior regularidade, no sentido de sinalizar certos pardmetros para o mercado, dada a situação inusitada da futuação sem qualquer delimitador."

14 "As vendas mensais líquidas de divisas externas pelo $B C B$, efetuadas tanto diretamente quanto por intermédio de qualquer instituição no papel de seu agente financeiro, serão limitadas aos seguintes valores: até US\$3.000 milhões em março de 1999; até US\$2.000 milhões em abril de 1999; até US\$1.500 milhões em maio de 1999, e até US\$1.500 milhóes em junho de 1999. O limite para um determinado mês $t$, onde t se refere a abril de 1999, maio de 1999 ou junho de 1999, será aumentado ou pela parcela não utilizada do limite de vendas líquidas de divisas externas do mês anterior (t-1), ou por 25 por cento do limite de vendas aplicável ao mês corrente $t$, o que for menor. Esses limites mensais de vendas líquidas de divisas externas constituem um critério de desempenho nos termos do programa para cada més do periodo de març-junho de 1999 e, como tal, podem ser revistos pela Diretoria Executiva do Fundo, se assim for exigido pelas circunstancias. Limites apropriados de vendas líquidas de divisas externas pelo BCB para o periodo de julho-dezembro de 1999 serão determinados durante a terceira avaliação do programa." (Memorando Técnico de Entendimentos com o FMI de 13/05/1999).

15 "Under the new floating exchange rate regime, central bank sales of foreign exchange in the market will be conducted regularly to meet the projected overall balance of payments financing needs. A limited amount of unsterilized intervention may be undertaken occasionally to counter disorderly market conditions. The central bank will refrain as from the beginning of March 1999 from intervening in the foreign exchange futures market." (Brazil Memorandum of Economic Policies March 8, 1999) 
parece consistente com uma flutuação tão pura quanto possível. ${ }^{16}$ Quanto ao segundo motivo, parece inconsistente com o princípio da flutuação livre, já que neste regime é o movimento da taxa de câmbio que tem o papel de conciliar o saldo em conta corrente com o financiamento disponível do balanço de pagamentos. De todo modo, no período que viria a seguir a questão não se colocou e a flutuação foi bastante livre.

\section{Fase 2: Sem medo de flutuar}

Esta segunda fase se estendeu por cerca de dois anos, indo do segundo trimestre de 1999 ao primeiro de 2001. Trata-se, sem dúvida, do período em que o regime cambial brasileiro mais se aproximou do padrão de flutuação pura. As intervenções do Banco Central no mercado de câmbio foram raras e de pequena monta, conforme mostrado no Gráfico 1.

Não foi apenas o fato de que o uso da reservas para estabilizar a taxa de câmbio caiu em desuso neste período. Também a política monetária foi conduzida da forma como se esperaria num regime de câmbio flutuante. Após ter elevado a taxa de juros básica para um pico de $45 \%$ para deter o overshooting cambial e o pass-through do câmbio para a inflação, na primeira fase acima descrita, o Banco Central passou a abrandar o rigor monetário nesta segunda fase. No segundo trimestre de 1999 a queda da taxa de juros foi relativamente rápida, e a partir do meio do ano prosseguiu de forma mais moderada. A política monetária passava a ser guiada pelas metas de inflação estabelecidas pelo Conselho Monetário Nacional. Não que a taxa de câmbio deixasse de ter qualquer influência sobre a condução da política de juros, mas esta passava a ser indireta, e apenas à medida que elevaçốes fortes da taxa de câmbio provocavam aumentos na taxa de inflação.

É interessante destacar que, utilizando os indicadores de Calvo e Reinhart (2000) de fear of floating, identificaríamos aqui uma característica de medo de flutuação, que seria a alta volatilidade da taxa de juros. Este seria, entretanto, um alarme falso, já que a forte queda dos juros no período, que produz a referida volatilidade, nada teve a ver com tentativas de conter a volatilidade cambial.

A decisão de buscar a flutuação pura certamente foi fortalecida, neste período de dois anos, pelo bom comportamento do novo regime. Primeiramente, ele havia permitido corrigir os preços relativos e a conta corrente sem perder o controle da inflação. De fato, como destacaram Goldfajn e Olivares (2001), uma combinação de circunstâncias

16 Nos EUA, durante o primeiro governo Reagan, quando o regime cambial se aproximou tanto quanto possível da flutuação pura, o subsecretário de Assuntos Monetários, Beryl Sprinkel, admitia que intervenções seriam admitidas em situações de desordem nos mercados - situação que exemplificou como aquela resultante de um atentado ao presidente da República. (FRANKEL \& DOMINGUEZ, 1993, p. 9). 
favoráveis permitiu um surpreendentemente baixo nível de pass-through da depreciação cambial para os preços. Em segundo lugar, como a taxa de câmbio fez parte do serviço de ajustamento - tarefa que anteriormente cabia principalmente ao instrumento taxa de juros -, foi possível reduzir o custo do dinheiro substancialmente em relação aos níveis prevalecentes durante o período do Plano Real (1994-98). Por fim, passado o ajustamento dos primeiros meses, a taxa de câmbio passou a exibir um razoável grau de estabilidade.

Até que ponto esse sucesso da "fase 2" foi garantido por circunstâncias favoráveis, porém efêmeras? Certamente um fator que tornou tudo mais fácil foi a oferta abundante de capitais externos que caracterizou o período. Como se pode ver no Gráfico 3, o influxo líquido de capitais por meio de empréstimos bancários, emissão de bônus, notas e commercial papers foi bastante positivo, com raras exceções, durante todo o período que vai do segundo trimestre de 1999 ao primeiro trimestre de 2001.

Em suma, na ausência de grandes turbulências, o Brasil não teve medo de flutuar. Esta situação iria, contudo, mudar no segundo trimestre de 2001.

\section{GRÁFICO 3 - INFLUXO LÍQUIDO DE EMPRÉSTIMOS BANCÁRIOS E VIA COLOCAÇÃO DE TÍTULOS (BÔNUS, NOTES ETC.) EM US\$ MILHÕES}

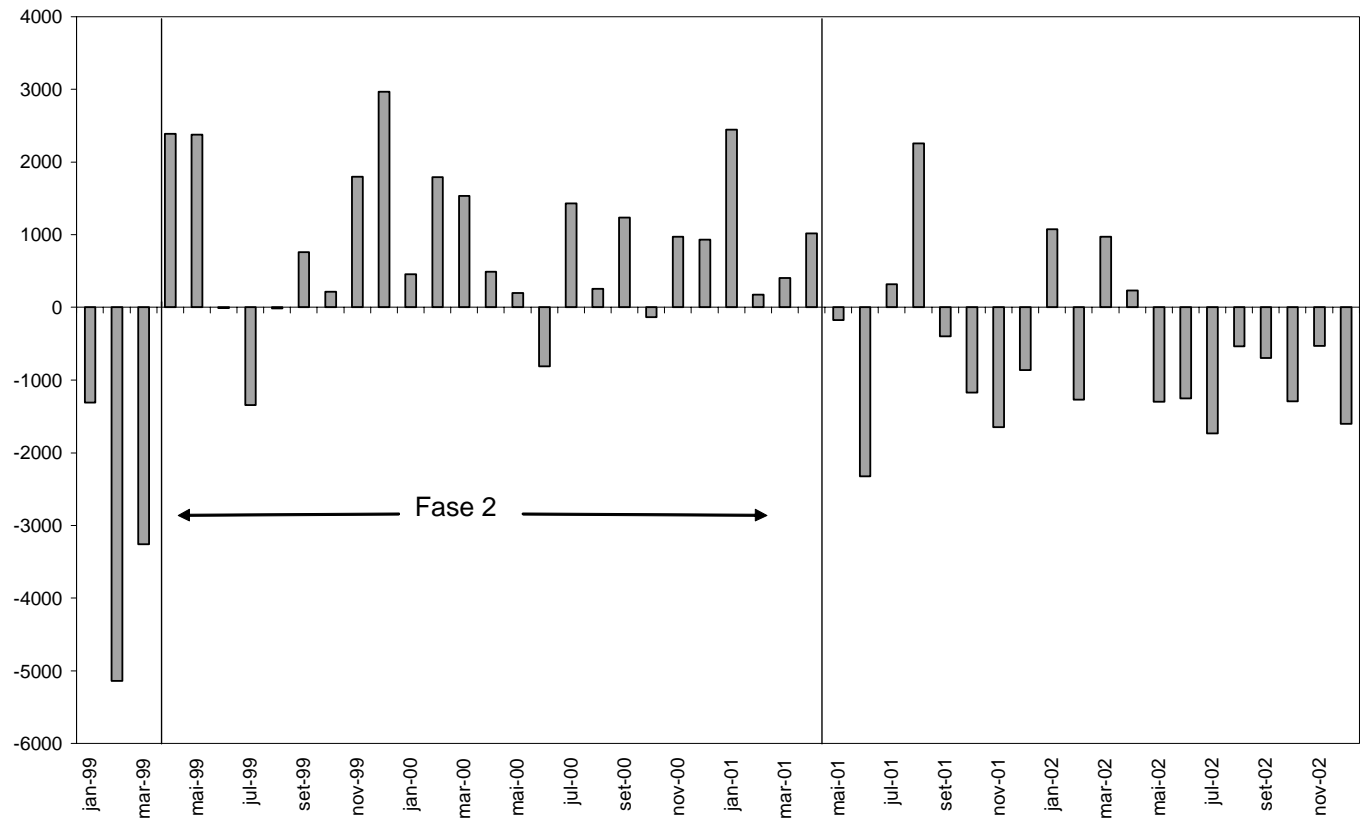

Fonte: Banco Central do Brasil, www.bcb.gov.br. Elaboração do autor. 
Fase 3: Ração diária e flutuação

Entre o primeiro e o segundo trimestres de 2001, quatro choques adversos reverteram radicalmente a conjuntura de bonança do período anterior. A conjugação da ruptura na base de sustentação política do governo com a crise energética, o aprofundamento da crise argentina e a recessão norte-americana provocou uma piora substancial nas perspectivas da economia brasileira. Seguiu-se então uma retração nos fluxos de capitais para o País, em simultâneo com um aumento da demanda por hedge cambial por parte das empresas com passivos em dólar. A conseqüência da combinação da redução da oferta com aumento da demanda por moeda estrangeira foi uma pressão no mercado de câmbio, que levou a uma disparada nas cotaçóes do dólar. Ao final do primeiro semestre a taxa de câmbio já havia alcançado um nível $20 \%$ superior ao do final do ano anterior. Em outubro, a depreciação acumulada no ano já havia escalado para $40 \%$.

Os distúrbios no mercado de câmbio foram tornando o Banco Central crescentemente preocupado com os impactos potenciais da depreciação da moeda sobre a inflação, conforme refletido nas atas mensais do COPOM. ${ }^{17}$ A reação do governo foi tentar conter a elevação da taxa de câmbio, atuando em três frentes principais: a intensificação da emissão de títulos públicos indexados ao dólar - como forma de atender à demanda por hedge cambial (Gráfico 4), a venda de reservas no mercado de câmbio (Gráfico 1) e a reversão da trajetória de redução da taxa de juros básica (Gráfico 5).

\section{GRÁFICO 4 - ESTOQUE DA DÍVIDA MOBILIÁRIA INDEXADA AO CÂMBIO (EM DÓLARES) E TAXA DE CÂMBIO NOMINAL}

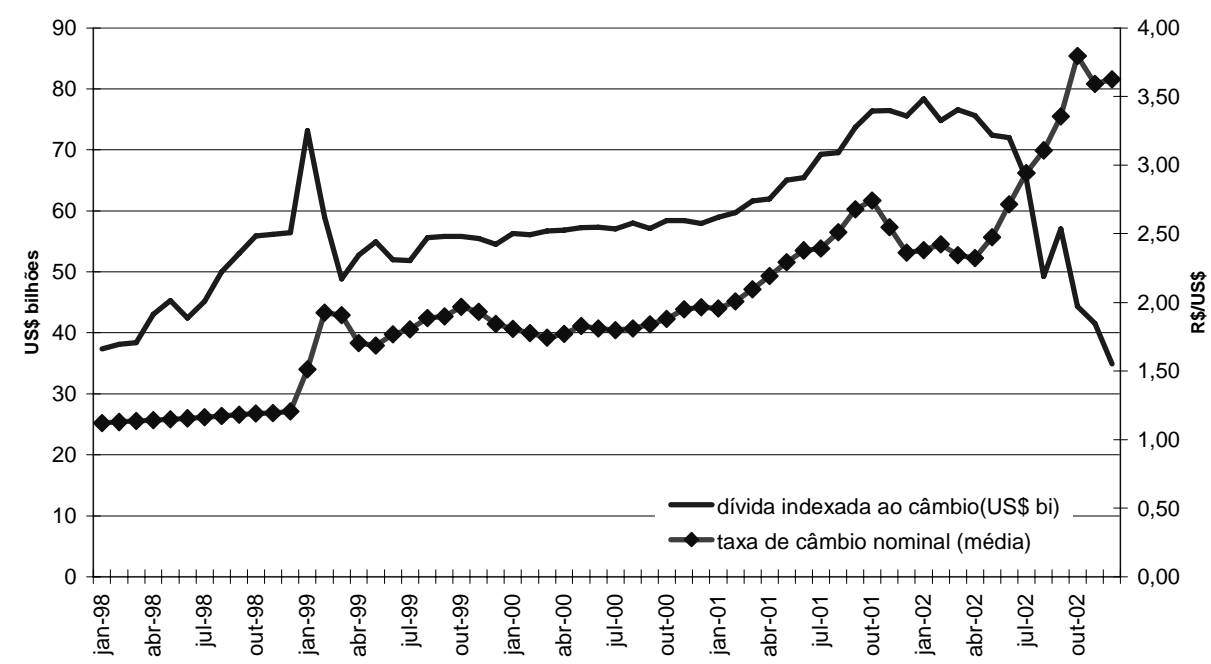

Fonte: Banco Central do Brasil, www.bcb.gov.br. Elaboração do autor.

17 Esta preocupação já se manifesta, por exemplo, nas Notas da $57^{a}$ Reunião do COPOM dos dias 20 e 21 de março de 2001. 
GRÁFICO 5 - TAXA DE JUROS SELIC (\% a.a.)

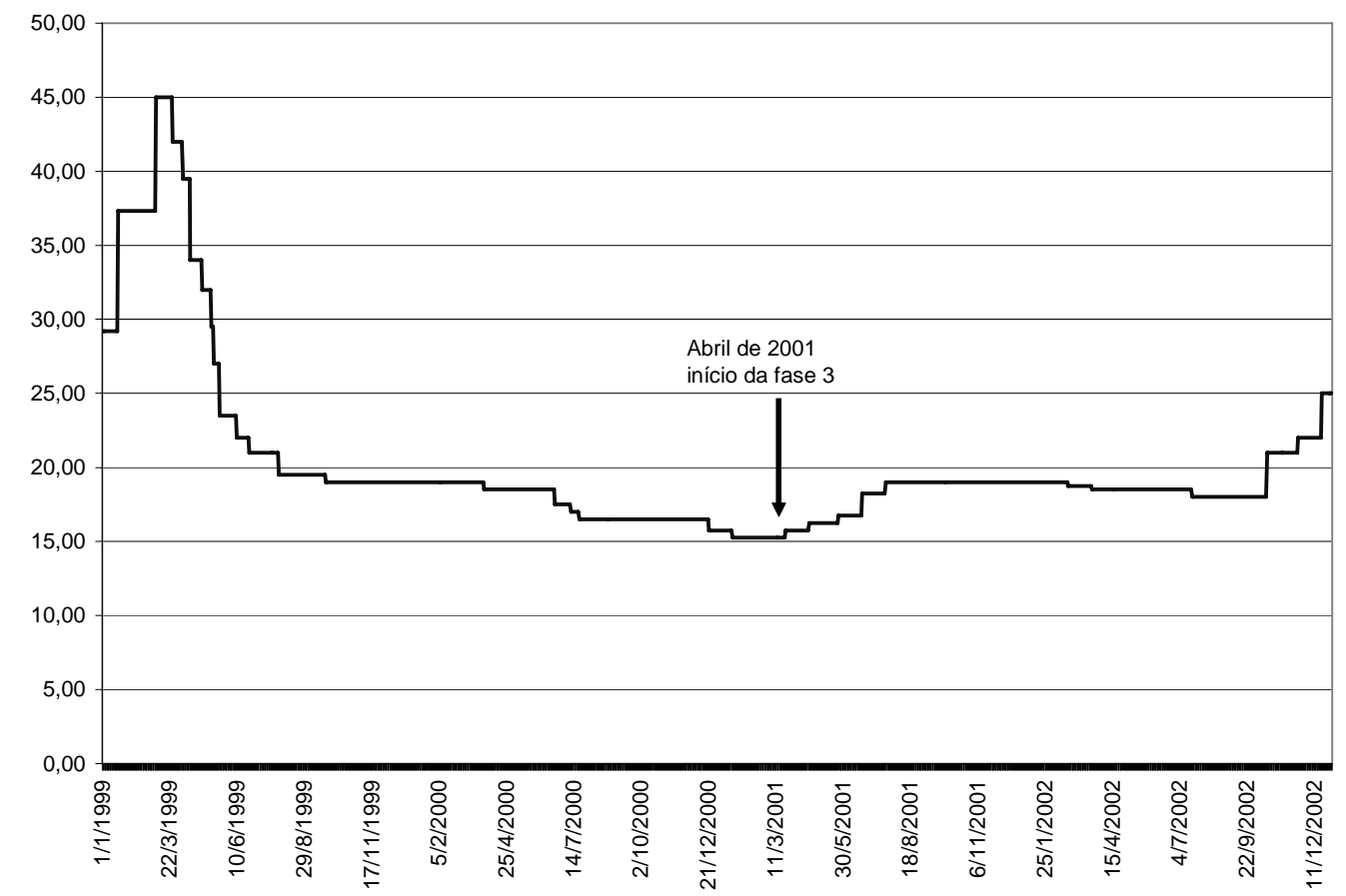

Fonte: Banco Central do Brasil, www.bcb.gov.br. Elaboração do autor.

Em meio ao conjunto de medidas acima, que em princípio podiam ser vistas como reveladoras de um medo de flutuar até então oculto, o Banco Central adotou uma nova estratégia, no que se refere às suas intervençôes no mercado de câmbio, com o objetivo de reafirmar que apesar de tudo seguia fiel à flutuação. A partir de julho, a instituição anunciou que venderia US\$ 50 milhões por dia (aproximadamente US\$ 1 bilhão por mês) ao longo do segundo semestre do ano, além de declarar a intenção de prosseguir com essa política no ano seguinte. A nova estratégia estava baseada na crença de que o ambiente hostil do segundo semestre imporia um fluxo anormalmente baixo de financiamento externo e, portanto, uma escassez de dólares no mercado, levando a um processo de depreciação cambial que seria reforçado por expectativas negativas. A idéia de vender uma quantidade fixa todos os dias - a ração diária - que deveria ser mantida mesmo em momentos em que o real eventualmente se apreciasse - era reduzir o tamanho da depreciação provocada pela escassez de financiamento externo (que se supunha temporária), sem tentar estabelecer qualquer meta para a taxa de câmbio. Com isso buscava-se evitar uma distorção nos sinais do mercado. Em suma, as autoridades monetárias tentavam intervir de uma maneira tal que seria, segundo argumentavam, compatível com o compromisso com o câmbio flutuante, isto é, determinado pelo mercado. 
Na avaliação de Kenen (2001), para que a nova estratégia do Banco Central se mostrasse consistente seria necessário que a instituição continuasse, por um período mínimo predefinido, a fazer suas vendas diárias de dólar, independentemente tanto de mudanças no ambiente do mercado que levassem a uma depreciação mais acentuada, quanto, alternativamente, a apreciaçôes da moeda nacional. Antecipando às dificuldades que tais alternativas poderiam colocar para a manutenção da política, Kenen sugeriu que as "raçôes diárias" fossem guiadas por uma "banda de monitoramento", conforme proposto por Williamson (2000). Estas dariam ao Banco Central uma justificativa técnica para alterar ou abandonar as vendas diárias quando a situação se modificasse muito. Este não foi, contudo, o caminho escolhido pelas autoridades monetárias, que prosseguiram com a mesma regra até que, ao verificar-se uma nova mudança no ambiente do mercado - que levou à apreciação cambial - simplesmente abandonaram a prática das vendas diárias de dólar.

Nos cinco meses que se seguiram, as intervenções no mercado de câmbio caíram a zero, as taxas de juros foram estabilizadas e depois reduzidas, de forma que, apesar do abandono da nova estratégia, o arranjo cambial voltou a parecer-se com a livre flutuação.

\section{Fase 4: $O$ regime monetário e cambial em xeque: asfixia cambial e fear of inflation}

A trégua que trouxe de volta a flutuação pura não durou muito. A partir de maio de 2002, uma nova crise de confiança emergiu, desta vez relacionada às incertezas quanto ao futuro da política econômica após as eleições presidenciais, diante da perspectiva da vitória do Partido dos Trabalhadores (pela primeira vez, desde a sua constituição), bem como pelo colapso da economia argentina e pelo aumento da aversão internacional ao risco a partir dos escândalos das fraudes fiscais em grandes corporações norteamericanas.

Desta vez, os efeitos da crise de confiança sobre o mercado cambial foram ainda mais fortes do que em 2001. O risco-País subiu de uma média de 734 pontos básicos em abril para um nível recorde em torno de 2.400 pontos no final de setembro de 2002 , provocando uma virtual interrupção dos fluxos de capitais para o Brasil a partir de junho. As cotações da moeda americana voltaram a disparar.

Uma vez mais, diante da crise no mercado de câmbio, o Banco Central lançou mão de diversas armas para enfrentar a forte depreciação do real. As taxas de juros foram elevadas, intervenções pesadas no mercado de câmbio foram retomadas por meio da venda direta de divisas e de linhas de crédito para exportação. Contudo, contrariamente a experiências anteriores, desta vez não houve aumento das vendas de títulos públicos in- 
dexados ao dólar. No entanto, a razão para isto foi a recusa do mercado em aceitar comprar tais títulos exceto a taxas inadmissíveis para o governo.

Por fim, um novo acordo foi assinado com o FMI, no âmbito do qual se negociou uma redução do piso líquido das reservas, de US\$ 15 bilhões para US\$ 5 bilhões, com a evidente intenção de ampliar o poder de intervenção do Banco Central no mercado de câmbio. ${ }^{18}$ As vendas de divisas no segundo semestre de 2002 chegaram a US\$ 8 bilhões, equivalentes a $30 \%$ da posição de reservas líquidas em 30 de junho daquele ano. Foi o período de maior intervenção vendedora no mercado de câmbio desde o início do regime de flutuação, como se pode ver no Gráfico 6 a seguir, que mostra a evolução do valor das intervençốes acumuladas em 6 meses. Ainda assim, a taxa de câmbio média mensal subiu $64 \%$ entre abril e o mês de outubro, quando ocorreram as eleiçốes presidenciais.

\section{GRÁFICO 6 - INTERVENÇÕES NO MERCADO DE CÂMBIO (VENDAS = +), ACUMULADAS EM 6 MESES (EM US\$ BILHÕES)}

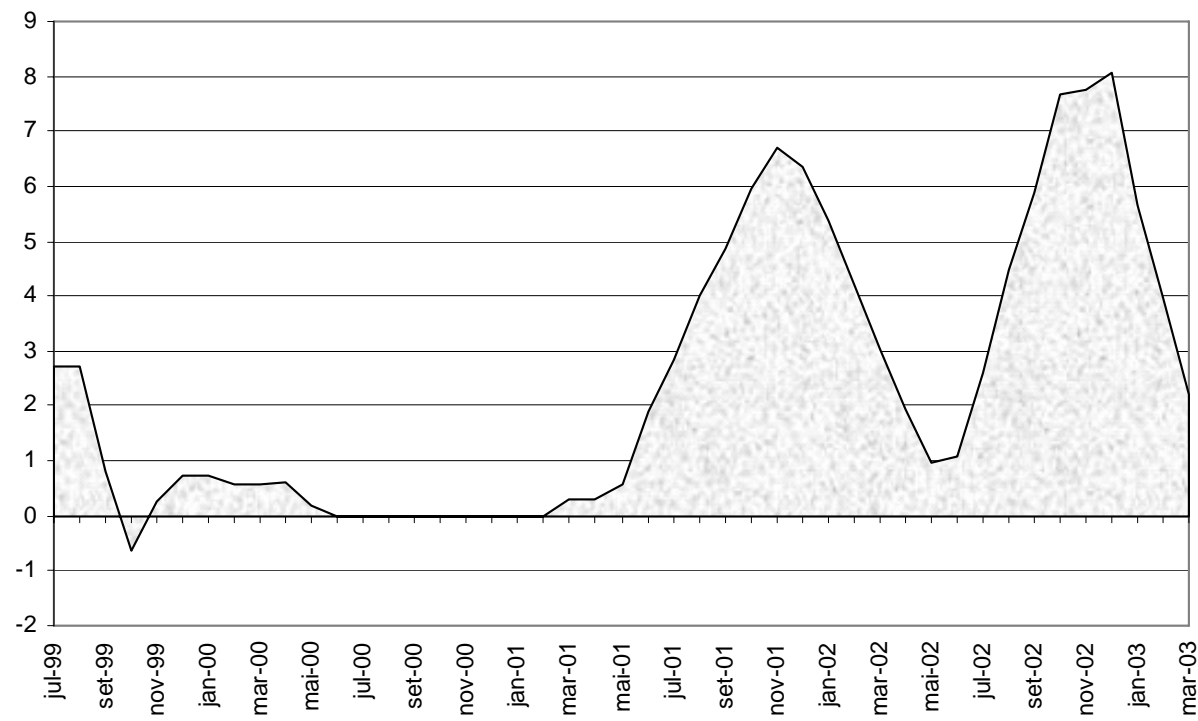

Fonte: Banco Central do Brasil, Notas para a Imprensa - Setor Externo, vários números. Elaboração do autor.

18 "A experiência deste e de anos anteriores confirma a importância do regime de taxa de cámbio flutuante para ajudar a economia a reagir a choques. Entretanto, a magnitude e 0 alcance dos recentes choques exigiram que 0 $B C B$ interviesse no mercado para reduzir parte da pressão sobre a taxa de cámbio. No caso de a intervenção atingir o valor acumulado de $U \$ 3,0$ bilhóes num periodo de 30 dias consecutivos, será iniciado amplo diálogo com o corpo técnico do FMI sobre as politicas monetárias e de intervenção. Nesse caso, o BCB já indicon que não abrandará as condições monetárias." (Memorando de Política Econômica enviado ao FMI em 04/09/2002). 
O esforço do governo para deter a escalada cambial estava associado ao medo da inflação sair de controle em meio ao eventual desmoronamento do regime de metas inflacionárias. Na avaliação do presidente do Banco Central, em sua carta aberta ao Ministro da Fazenda para justificar o não cumprimento da meta inflacionária em 2002, da inflação verificada de $12,5 \%$ no ano, 5,8 pontos porcentuais poderiam ser atribuídos aos efeitos da depreciação do real ante o dólar. E mais, começava a ficar evidente que o afastamento tão grande da inflação efetiva em relação à meta (de 3,5\%) fez com que o regime de metas inflacionárias começasse a perder credibilidade. ${ }^{19}$ A alternativa para conter a inflação seria um eventual restabelecimento de alguma forma de âncora cambial. Em suma, os regimes monetário e cambial estavam em xeque.

\section{RAZÕES PARA DESEJAR E TEMER A FLUTUAÇÃO NO CASO BRASILEIRO}

A incerteza reinante na economia brasileira ao final de 2002 trouxe de volta o risco de se ter que recorrer ao câmbio como âncora, já que o sistema de metas começou a ruir. No entanto, a nova administração empossada em janeiro de 2003 rejeitou esta hipótese, e desde o início optou por manter a flutuação e o regime de metas inflacionárias, empenhando-se em resgatar a credibilidade da política monetária, apesar dos custos políticos que isto significou para o governo do Partido dos Trabalhadores. Por que a opção foi reiterada? Em outras palavras, o que levou o governo de FHC, que implementou o regime de câmbio flutuante, a usar uma artilharia pesada para tentar estabilizar o câmbio no segundo semestre de 2002, e o novo governo de Lula a restabelecer a livre flutuação?

De um lado, não é difícil encontrar razões para desejar a flutuação. Basta verificar os problemas associados aos regimes alternativos: alta vulnerabilidade a crises cambiais e ataques especulativos devastadores, no caso dos chamados regimes intermediários; e a renúncia ao uso do câmbio como mecanismo de ajustamento do balanço de pagamentos e a perda da autonomia para praticar política monetária, no caso da dolarização ou união monetária. Tendo passado por uma grave crise cambial em 1998 e início de 1999, o Brasil tinha razões para desejar e optar pela flutuação. E isto foi feito com um grau de convicção que levou este regime a fazer parte - juntamente com as metas inflacionárias e o superávit primário do setor público - do chamado tripé de política econômica, que desde então passou a ser defendido por um amplo espectro de economistas dentro e fora do governo.

19 A crise de credibilidade do regime de metas pode ser aferida pelo fato de que, pela primeira vez desde a sua implantação, se verificou uma acentuada divergência entre as metas fixadas pelo governo e as expectativas inflacionárias apuradas pelo Banco Central por meio de uma pesquisa realizada com um grande número de instituiçóes do mercado. (Focus). Assim, em dezembro de 2002 as expectativas do mercado eram de uma inflação, medida pelo IPCA, de 10,8\% para 2003, ultrapassando em muito a meta de $4 \%$ fixada 6 meses antes. As metas estavam claramente perdendo seu papel de instrumento de coordenação das expectativas. 
Por outro lado, há também razões para temer a flutuação. Na literatura sobre fear of floating tende-se a destacar os impactos do câmbio sobre a inflação e, principalmente, os efeitos da volatilidade da taxa de câmbio sobre as economias emergentes que sofrem do mal do "pecado original", isto é, do descasamento monetário entre ativos e passivos. Em que medida estes dois riscos foram importantes para o intervencionismo observado nos segundos semestres de 2001 e 2002?

No que se refere ao segundo risco, o argumento é que, sendo o passivo dolarizado da economia muito maior do que o ativo, desvalorizaçóes cambiais provocam desequilíbrios patrimoniais nas empresas, produzindo graves dificuldades financeiras, que geram uma retração dos investimentos e a queda da produção e do emprego. Em suma, a depreciação cambial teria efeitos contracionistas, em lugar de ser um instrumento de promoção de um ajuste saudável para a economia. No caso da economia brasileira, contudo, a própria flutuação intensa ocorrida desde 1999 (conforme visto no exame da Tabela 1) contribuiu para o desenvolvimento do mercado de hedge cambial, conforme esperado por diversos autores (vide, por exemplo, GOLDFAJN \& OLIVARES, 2001). É verdade, contudo, que como a economia é liquidamente devedora em relação ao resto do mundo, por mais desenvolvido que esteja este mercado, haverá para o conjunto da economia uma posição não protegida, isto é, um descasamento monetário no agregado.

Especificamente no caso brasileiro, o descasamento monetário global não se distribuiu igualmente pela economia. Ao contrário, enquanto o setor privado conseguiu, em grande medida, se proteger da exposição cambial no mercado de hedge, o setor público tornou-se um ofertante líquido de proteção cambial para o resto da economia. Uma implicação importante deste fato é que o setor privado pode suportar relativamente bem grandes depreciações cambiais. Assim, apesar das fortíssimas depreciações cambiais de 1999, 2001 e 2002, que vieram combinadas com altíssimas taxas de juros, a economia não chegou a entrar em recessão, porque o problema do descasamento cambial afetou de forma muito grave apenas algumas empresas, localizadas sobretudo no setor de infra-estrutura. Por outro lado, o setor público foi fortemente atingido pelas sucessivas desvalorizações cambiais, devido à sua dívida em dólares (externa e interna indexada ao dólar). A conseqüêencia foi a forte elevação da relação dívida pública/PIB, de 41,7\% em 1998 para 56,5\% em dezembro de 2002, apesar do crescente esforço fiscal realizado. O impacto da depreciação cambial sobre a dívida pública pode ser avaliado pela informação do Banco Central de que somente no biênio 2001-2002 a depreciação contribuiu para uma elevação da dívida pública equivalente a 12,5 pontos porcentuais do PIB (ou aproximadamente 85\% de todo o aumento da dívida pública entre 1998 e 2002). 
O custo do descasamento cambial recaiu, portanto, sobre o setor público. Entretanto, é importante notar aqui que se a taxa de câmbio real estivesse apenas oscilando em torno de um determinado nível de equilíbrio, a conseqüência seria uma flutuação da relação dívida pública/PIB - que baixaria nos momentos de apreciação real e subiria nos momentos de depreciação real. Não haveria, em princípio, um prejuízo para o setor público. O problema foi que desde a implantação do câmbio flutuante ocorreu uma enorme depreciação real da moeda doméstica, que não foi revertida.

Em suma, no que se refere aos riscos associados ao descasamento monetário, o problema no Brasil esteve mais associado à forte depreciação real que se seguiu à mudança do regime cambial do que à volatilidade da taxa de câmbio. Não seria, a princípio, um problema a partir de então. Mas, o que dizer do outro motivo para temer a flutuação, a saber, o medo da inflação?

Uma das razóes pelas quais o regime de câmbio flutuante ganhou tanta adesão no Brasil foi que nos primeiros anos após a sua implantação o coeficiente de pass-through da depreciação para os preços foi relativamente baixo. Uma das principais razões para isso talvez tenha sido o grau de apreciação real prévio. ${ }^{20}$ A situação no segundo semestre de 2002 era, no entanto, bastante distinta. De acordo com a Carta Aberta do Presidente do Banco Central ao Ministro da Fazenda, de 21/01/03, o coeficiente de repasse da depreciação cambial para os preços evoluiu de uma média histórica de $7 \%$ para um nível de $17 \%$ no último trimestre de 2002. O medo da inflação passou então a influir mais decisivamente na postura do Banco Central em relação à taxa de câmbio. Contudo, mais uma vez o problema não parece ser bem caracterizado como medo de flutuar e sim como medo de que um câmbio determinado pelo mercado acabe provocando um desalinhamento muito acentuado do valor da moeda.

Existe, entretanto, uma assimetria a ser registrada. Uma eventual apreciação real prolongada da moeda doméstica não tende a colocar as autoridades monetárias sob pressões semelhantes (às geradas pela depreciação) para intervir no mercado de câmbio. $\mathrm{E}$ isto tanto por razões técnicas - o fato de que a apreciação não põe em risco o cumprimento das metas inflacionárias, pelo contrário, facilita esta tarefa - como também por razões políticas relacionadas ao conforto econômico produzido pela apreciação. Contudo, ela encerra um risco elevadíssimo de gerar ou aprofundar um desequilíbrio em transações correntes cujo desfecho futuro seria inevitavelmente uma crise cambial com conseqüências recessivas.

Em síntese, parece muito mais difícil para um país como o Brasil aceitar um desalinhamento continuado da taxa de câmbio do que uma alta volatilidade mensal. Ou seja, o

20 GOLDFAJN \& WERLANG (2000) examinam os diferentes fatores determinantes do grau de pass-through e concluem que a apreciação ou depreciação real prévia é um dos mais importantes. 
problema maior da flutuação não parece ser, para países como o Brasil, de volatilidade, mas das conseqüências - inflacionárias ou de desequilíbrio do balanço de pagamentos - de desalinhamentos prolongados. Para ilustrar este ponto, observe-se o Gráfico 7, que mostra a taxa de câmbio real efetiva da moeda brasileira, adotando-se como base 100 a média do período 1970-2002. Nele também se mostra a volatilidade das reservas, medida pelas intervenções do Banco Central, como proporção das reservas, com o objetivo de estabilizar a taxa de câmbio. Como se pode verificar, as intervençóes se tornam mais intensas quando o afastamento em relação à média do período se torna maior (o nível ao redor do índice 140 parece constituir uma espécie de fronteira do aceitável), independentemente da volatilidade mensal do câmbio.

\section{GRÁFICO 7 - TAXA DE CÂMBIO REAL EFETIVA $(1970-2002=100)$ E VARI- AÇÃO MENSAL (\%) DAS RESERVAS}

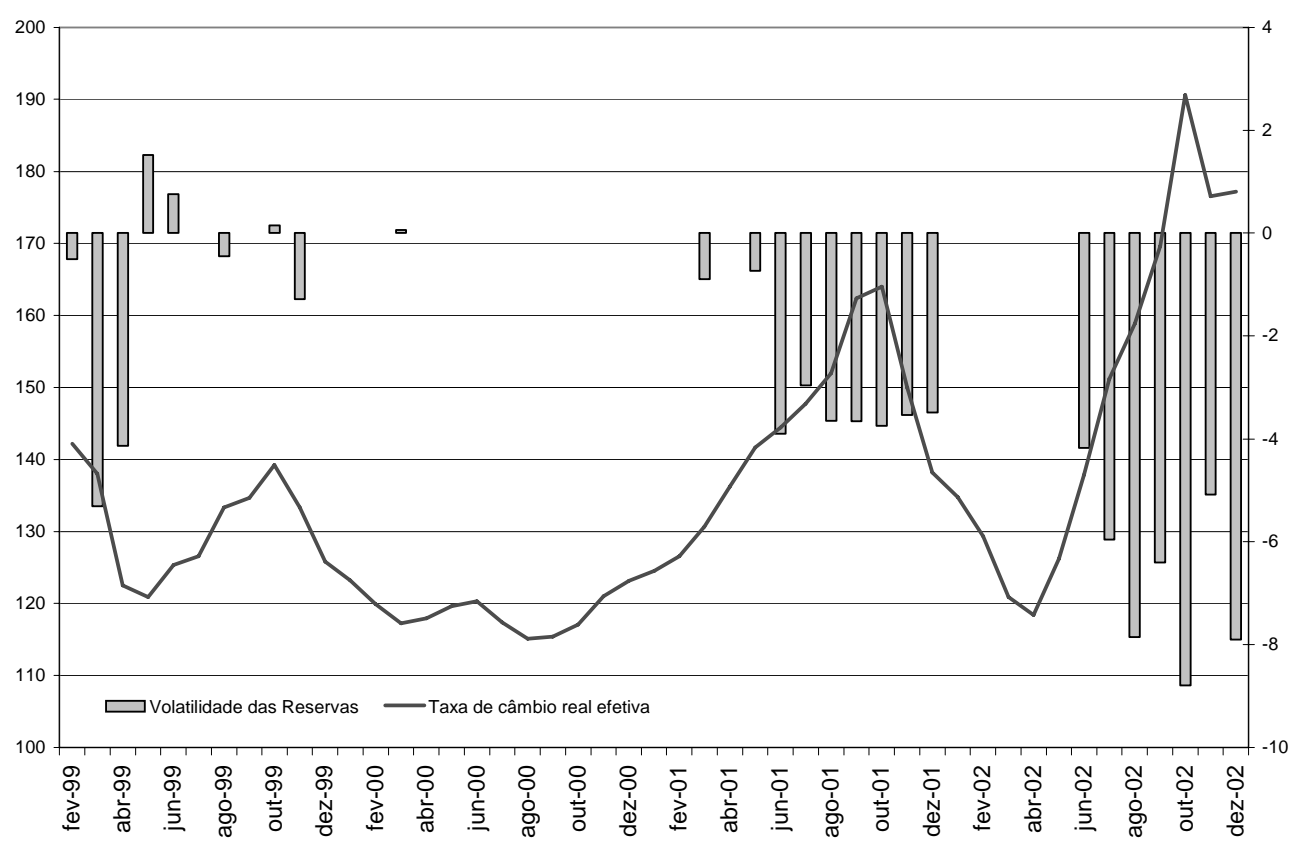

Fontes: Banco Central do Brasil (www.bcb.gov.br); IBGE; IMF, International Financial Statistics.

\section{CONCLUSÃO}

Nos últimos quatro anos as autoridades brasileiras têm se pronunciado, de forma inequívoca, em favor do regime de câmbio flutuante. No entanto, esta opção não fica tão clara quando se faz uma análise comparativa do caso brasileiro com os de outros países que praticam uma flutuação genuína. Utilizando-se indicadores do tipo "Calvo-Rei- 
nhart" para o período 1999-2002 como um todo, o Brasil exibe alguns indícios de fazer parte do grupo de países que apresenta fear of floating. Em comparação com Estados Unidos e Japão, a freqüência do uso das reservas e dos juros (além de outras formas indiretas de intervenção) para restringir depreciações cambiais tem sido relativamente elevada. Por outro lado, a volatilidade da taxa de câmbio tem sido muito maior, o mesmo podendo-se dizer dos processos de desalinhamento cambial. Isto coloca em dúvida se a principal diferença entre o caso brasileiro e o dos países de referência é uma disposição menor das autoridades brasileiras em deixar o real flutuar ou se é a magnitude dos choques a que esteve sujeita esta economia, dada a sua alta dependência de fluxos de capital externo para equilibrar o balanço de pagamentos.

Para se fazer um diagnóstico mais conclusivo recorreu-se a uma decomposição da ação das autoridades monetárias por períodos. Assim procedendo, foi possível verificar que há intervalos de tempo relativamente longos em que o comportamento do regime cambial efetivamente se aproxima da flutuação genuína. $\mathrm{O}$ afastamento deste padrão ocorre não quando a taxa de câmbio varia muito, mas quando ela começa a mostrar uma tendência sistemática ao desalinhamento. Em tais casos, diante do risco de retorno da inflação e do desmoronamento da política monetária, intervençóes acontecem e as autoridades demonstram, supostamente, "medo da flutuação". Este, entretanto, como visto, nada tem a ver com o diagnóstico de fear of floating de Calvo e Reinhart (2000). De fato, passadas as fases críticas, verificou-se uma "volta à normalidade" da flutuação (o que se verificaria novamente a partir do início de 2003).

Em suma, a flutuação cambial, embora tenha trazido grande margem de manobra para a política econômica e, por isso mesmo, venha tendo grande aceitação no Brasil, não resolveu, de imediato, o problema da vulnerabilidade externa da economia. No período 1999-2002, apesar dos avanços, a economia se manteve excessivamente exposta a choques financeiros, que produziram desalinhamentos cambiais inassimiláveis sem graves distúrbios internos. Assim sendo, pelo menos enquanto os fundamentos externos da economia brasileira não estiverem suficientemente consolidados, o recurso a instrumentos que evitem desalinhamentos cambiais excessivos deve ocorrer sempre que situações extremas ponham em risco o controle da inflação ou a estabilidade do balanço de pagamentos. Ainda assim resta um amplo espaço para a flutuar sem medo - seja pela adoção do regime de metas de inflação (que oferece uma âncora alternativa ao câmbio), seja pelo desenvolvimento do mercado de hedge cambial. Neste sentido, o regime brasileiro aproxima-se mais do que Goldstein (2002) chamou de managed floating plus. 


\section{REFERENCIAS}

BANCO CENTRAL DO BRASIL. Análise do mercado de câmbio, relatório trimestral. Jan-mar de 1999. Disponível em http://www.bcb.gov.br/?RELCAMBIO.

. Atas da $57^{a}$ reunião do COPOM. Disponível em http://www.bcb.gov.br/? COPOM57.

CALVO, G. A.; REINHART, C. M. Fear of floating. NBER Working Paper, n. $7993,2000$.

EICHENGREEN, B. International monetary arrangements for the $21^{\text {st }}$ century. Washington D.C.: Brookings Institution, 1994.

. Can emerging markets float? Should they inflation target? Banco Central do Brasil, Working Paper 36, 2002.

EICHENGREEN, B., HAUSMANN, R.; PANIZZA, U. Original sin: the pain, the mystery and the road to redemption. Inter-American Development Bank, Conference on Currency and Maturity Matchmaking: Redeeming Debt from Original Sin, 2002.

FISCHER, S. Exchange rate regimes: is the bipolar view correct? Disponível em: http://www.imf.org/external/np/speeches/2001/010601a.pdf, 2001.

FRANKEL, J. A.; DOMINGUEZ, K. Does foreign exchange intervention work? Washington D.C.: Institute for International Economics, 1993.

FRANKEL, J. A. No single currency regime is right for all countries or at all times. NBER Working Paper, n. 7338, 1999.

FMI. Annual report on exchange arrangements and exchange restrictions. 1999.

GOLDFAJN, I.; OLIVARES, G. Can flexible exchange rates still 'work' in financially open economies? G-24 Discussion Paper, n. 8, 2001.

GOLDFAJN, I.; WERLANG, S. The pass-through from depreciation to inflation: a panel study. Departamento de Economia, PUC-Rio, Working Paper, n. 423, 2000 .

GOLDSTEIN, M. Managed floating plus. Institute for International Economics, 2002.

HAUSMANN, R.; PANIZZA, U.; STEIN, E. Why do countries float the way they float? Inter-American Development Bank, Working Paper 418, 2000.

HAUSMANN, R.; GAVIN, M.; LEIDERMAN, L. The macroeconomics of capital flows to Latin America: experience and policy issues. Inter-American Development Bank, Working Paper 310, 1995.

KENEN, P. Daily dollar sales and beyond. Nota técnica do Banco Central do Brasil, n. $9,2001$.

McKINNON, R.; SCHNABL, G. The East Asian dollar standard, fear of floating, and original sin. Disponível em: http://www.stanford.edu/ $\sim$ mckinnon/papers.htm, 2003. 
MUSSA, M. et al. Exchange rate regimes in a increasingly integrated world economy. Washington, D.C.: IMF Occasional Paper, 2000.

REINHART, C. M. The mirage of floating exchange rates. American Economic Review, v. 90, n. 2, p. 65-70, 2000.

SILVEIRA, M. A. C. da. Intervenção da autoridade monetária no mercado de câmbio em regime de flutuação administrada. Nota técnica do Banco Central do Brasil, $\mathrm{n}^{\mathrm{O}} 34,2003$.

STURZENEGGER, F.; LEVYYEYATI, E. Classifying exchange rate regimes: deeds vs words. Universidad Torcuato Di Tella, 2002.

WILLIAMSON, J. Exchange rate regimes for emerging markets: reviving the intermediate option. Washington, D.C.: Institute for International Economics, 2000. 
ANEXO I - VOLATILIDADE DA TAXA DE CÂMBIO (FINAL DO PERÍODO)

\begin{tabular}{|c|c|c|c|c|}
\hline \multirow[t]{2}{*}{ País } & \multirow[t]{2}{*}{ Período } & \multicolumn{3}{|c|}{ Freqüência na qual a variação mensal da taxa de câmbio: } \\
\hline & & $\begin{array}{l}\text { Ficou dentro da } \\
\text { banda de }+/-1 \%\end{array}$ & $\begin{array}{c}\text { Ficou dentro da } \\
\text { banda de }+/-2,5 \%\end{array}$ & $\begin{array}{c}\text { Excedeu a } \\
\text { banda de }+/-2,5 \%\end{array}$ \\
\hline Turquia & jan/99 a set/02 & $11 \%$ & $22 \%$ & $78 \%$ \\
\hline Argentina & jan/02 a dez/02 & $8 \%$ & $25 \%$ & $75 \%$ \\
\hline África do Sul & jan/99 a dez/02 & $25 \%$ & $48 \%$ & $52 \%$ \\
\hline Brasil & jan/99 a dez/02 & $8 \%$ & $48 \%$ & $52 \%$ \\
\hline Nova Zelândia & jan/99 a dez/02 & $21 \%$ & $50 \%$ & $50 \%$ \\
\hline Chile & jan/99 a dez/02 & $23 \%$ & $54 \%$ & $46 \%$ \\
\hline Austrália & jan/99 a dez/02 & $23 \%$ & $58 \%$ & $42 \%$ \\
\hline EUA (dólar/euro) & jan/99 a dez/02 & $35 \%$ & $58 \%$ & $42 \%$ \\
\hline Japão & jan/99 a dez/02 & $31 \%$ & $58 \%$ & $42 \%$ \\
\hline Polônia & jan/99 a set/02 & $36 \%$ & $64 \%$ & $36 \%$ \\
\hline México & jan/99 a dez/02 & $31 \%$ & $65 \%$ & $35 \%$ \\
\hline Paraguai & jan/99 a out/02 & $46 \%$ & $72 \%$ & $28 \%$ \\
\hline Uruguai & jan/99 a out/02 & $48 \%$ & $72 \%$ & $28 \%$ \\
\hline Coréia do Sul & jan/99 a dez/02 & $33 \%$ & $77 \%$ & $23 \%$ \\
\hline Tailândia & jan/99 a dez/02 & $49 \%$ & $79 \%$ & $21 \%$ \\
\hline Venezuela & jan/99 a dez/02 & $44 \%$ & $79 \%$ & $21 \%$ \\
\hline Israel & jan/99 a out/02 & $37 \%$ & $80 \%$ & $20 \%$ \\
\hline Canadá & jan/99 a dez/02 & $44 \%$ & $90 \%$ & $10 \%$ \\
\hline Rússia & jan/99 a out/02 & $72 \%$ & $91 \%$ & $9 \%$ \\
\hline Cingapura & jan/99 a dez/02 & $52 \%$ & $92 \%$ & $8 \%$ \\
\hline Brasil (1) & jul/95 a dez/98 & $93 \%$ & $100 \%$ & $0 \%$ \\
\hline EUA (dólar/marco) & $\mathrm{fev} / 73$ a abr/99 & $27 \%$ & $59 \%$ & $41 \%$ \\
\hline
\end{tabular}

Fontes: CALVO \& REINHART (2000), Banco de Dados do Grupo de Conjuntura (UFRJ), Fed, IFS, Banco Central do Chile, Ministério da Economia Argentina.

(1) Período do Plano Real em que a taxa de câmbio era fixada.

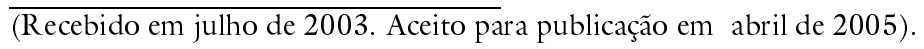

